\title{
COPPER METABOLISM AND THE LIVER
}

\author{
J. M. WALShe, M.R.C.P. \\ Department of Experimental Medicine, University of Cambridge
}

SitTing as it does astride the portal circulation, the liver is intimately connected with regulating the plasma concentrations of many, if not all, substances absorbed from the gut. Copper is no exception to this rule for although it is, physiologically speaking, a trace metal in man it is an ubiquitous element in nature and is found in many articles of diet and in significant amounts in drinking wat $e r$ since the introduction of copper pipes into household plumbing (surely a word whose etymology has now left it in an untenable position). The normal diet contains 2 to $4 \mathrm{mg}$. of copper per day and a number of foods are particularly rich in this element, such as shell fish with their copper-containing respiratory pigment, nuts, chocolate, mushrooms, liver and many cereals particularly if these are grown on copper-rich soils. Either by accident or, more probably, by design copper is poorly absorbed from the gut and about $70 \%$ of an orally administered dose is recoverable in the fæces (Van Ravestyn, 1944). Little copper is excreted in the urine, probably less than $50 \mu \mathrm{g}$. daily by normal adults, and the main route of excretion is via the bile and possibly the gut wall (Adelstein and Valee, 196r).

The copper ion is much too reactive to exist free in the body and, for that matter, too powerful an enzyme poison to be allowed to come in contact with the intracellular enzymes (Rees, 1962). Once in contact with protein copper rapidly becomes bound to $-\mathrm{SH},-\mathrm{COOH}$ or $-\mathrm{NH}_{2}$ radicles in decreasing order of affinity. Apart from these non-specific copper-protein bindings there are a number of true copper-proteins in the body with a constant copper-protein ratio and, in a number of cases, a known enzyme action, examples being cytochrome $\mathrm{C}$ oxidase, tyrosinase and uricase. There are other well documented copper-proteins whose enzyme action or specific function, though such probably exists, is at present unknown, for instance cerebrocuprein, liver - copper - protein erythrocuprein and cæruloplasmin, the blue copperprotein of plasma (Porter, I962; Morell, Shapiro and Scheinberg, 1962; Scheinberg and Sternlieb, 1960).

Although copper, with its integral role in the formation of a number of metallo-proteins, is an essential element in man, there are no weth recorded examples of a dietary deficiency of the element such as occur in animals leading to anæmia, demyelinating diseases, myocardify fibrosis, loss of fertility and achromotrichia, the particular manifestion varying with the species (Adelstein and Valee, 196I). The normal bod content of the metal is around $100 \mathrm{mg}$. (Adelsteif and Valee, I96r), the highest concentration being found in liver, kidney, heart and brain (Cartwright, Hodges, Gubler, Mahoney, Daumº Wintrobe and Bean, 1954; Bickel, Neale and Halb I957; Cumings, r959), with very high concentrations in such pigmented areas of the brain as the substantia nigra and the locus cæruleus (Ear로. 1962).

Much information has been gained on \&hष् intimate handling of copper in the body by usesof the radioactive isotope ${ }^{64} \mathrm{Cu}$, the limiting faceo being the short half life of 12.8 hours. After or adminstration of copper it rapidly appears in the plasma where it is attached to the albumin bu得 within a few hours the concentration of the isotope falls and then shows a secondary ris $\overrightarrow{\vec{E}}$ which commonly exceeds the initial peak and $i \bar{z}$ due to the appearance of radiocopper bound int the cæruloplasmin molecule (Bearn and Kunkep. 1955). Bush, Mahoney, Markowitz, Guble Cartwright and Wintrobe (1955) showed that after intravenous administration copper was concentrated in the liver where, presumably. the incorporation of the metal into cæruloplasmio occurs. More detailed studies have been made by Osborn, Roberts and Walshe (1963) who have shown that normal individuals concentrate the metal very rapidly in the liver, about $50 \%$ of the dose being taken up within 15 minutes of injection and between 60 and $90 \%$ in 4 hours. The only other sites over which active concentration of the isotope can be detected are the kidneys (Sass్ Kortsak, 1962; Osborn and Walshe, 1963). This very rapid concentration of copper and incorpora? tion into the serum protein cæruloplasmin by th liver suggests that a specific uptake mechanism exists which is, in some ways, reminiscent of the uptake of iodine by the thyroid. In the neonatad period the ability of the liver to synthesize 
cæruloplasmin is not fully developed and adult levels of the protein are not found in the blood till about three months of age. It is interesting therefore that the infant liver has a very much higher copper content than is found in the adult and a fall in concentration does not takes place until the ability to synthesize cæruloplasmin has fully developed (Richterich, 1962).

The function of cæruloplasmin remains a mystery (Holmberg, 1962) despite much detailed and painstaking research. It is an alpha globulin of molecular weight $15 \mathrm{I}, 000$; it has a characteristic blue colour (as the name will readily make apparent to all classical scholars) and each molecule contains 8 atoms of copper which appear to be arranged in functional pairs (Holmberg and Laurell, 1947; Scheinberg and Sternlieb, 1960). It has a weak oxidase activity for certain polyphenols and polyamines, notably adrenaline and serotonin but its physiological substrate, if any, is unknown. The liver, besides this ability to extract copper and incorporate it into the cruloplasmin molecule, also synthesises another metallo-protein, hepatocuprein which has been isolated and characterized by Morrell, and others (1962). Like cæruloplasmin its function is unknown but it has no oxidase activity and may well be a storage protein or cæruloplasmin precursor.

As the main route of copper excretion is via the bile, it is not surprising that copper accumulates in the liver in patients with long standing obstructive jaundice and biliary cirrhosis. There is also a modest increase in hepatic copper in patients with portal cirrhosis (Gubler, Brown, Markowitz, Cartwright and Wintrobe, 1957). Very high levels of hepatic copper are found in the ill defined syndrome 'juvenile cirrhosis', described by Butt, Nusbaum, Gilmour and DiDio (1958), but since a number of the patients died in the neonatal period it is difficult to be certain to what extent the values reported are influenced by the elevated hepatic copper levels which are commonly found in this age group. However, in older children the very high concentrations of metal which were found suggest a cause-and-effect relationship with the cirrhosis, particularly in view of the known toxicity of copper for sulphydryl enzymes. Indeed the concentrations of copper found in the liver of these children were, on average, higher than those found in the other copper storage disease, hepatolenticular degeneration (Wilson's disease). It might at first seem as though the separation of patients with these two diseases would be difficult if indeed it existed, especially since it has recently been shown that nearly $50 \%$ of all cases of Wilson's disease are first seen before the age of about 12 years with evidence of liver damage and neurological manifestations are uncommon till after puberty. Study of the other trace metal patterns in these two conditions does however suggest that they are two distinct entities. For instance in Wilson's disease storage of copper is not confined to the liver but is also found in brain, heart, kidneys and bone and is always accompanied by silver storage, findings which were not made in patients with 'juvenile cirrhosis' (Butt, and others, 1958). Distribution of copper within the liver was also different in the two groups, another distinction which supports the specific individuality of Wilson's disease. It is of interest that feeding excess copper to rats leads to cirrhosis without brain storage of the metal (Wolff, 1960), further suggesting that different mechanisms are involved in the pathogenesis of these diseases. Studies with radiocopper of a case of 'juvenile cirrhosis' with hepatic storage (Osborn and Walshe, 1963 ) show that the isotope is concentrated by the liver at a rate which falls nearer to the normal than to the Wilson's disease range, in fact the handling was within the wide range found for patients with other types of cirrhosis (Osborn and others, 1963); in addition the blood levels of the isotope were much lower than have been found in patients with Wilson's disease after intravenous injection, but the 24-hour to 2-hour ratio was reduced suggesting either a delayed synthesis of cxruloplasmin (the enzyme assay gave a value of $20 \mathrm{mg}$./ $100 \mathrm{ml}$.) or else dilution of the isotope in the greatly expanded liver pool of copper. In their study of trace-metal patterns in disease Butt and his associates (1958) confined themselves to post-mortem material so there are, unfortunately, no details of blood and urine copper levels in patients with 'juvenile cirrhosis'. In the patient studied by Walshe and Osborn the urine excretion of copper was normal as were the values for serum copper and cæruloplasmin before the onset of treatment with penicillamine.

Unfortunately we must conclude that the information at present available about 'juvenile cirrhosis' is not adequate to enable us to form a clear conception of the disease and the relationship of the copper to the liver lesion or even to decide if the presence of the metal is the cause or the effect of the cirrhosis. In Wilson's disease, on the other hand, there is no shortage of information about the disturbed copper metabolism although its role in the pathogenesis is still in doubt. An abnormality of copper metabolism had been suspected for many years, but it was not until Cumings (1948) analysed the brains and livers of a number of patients dying of this disease that the copper storage was convincingly documented. About the same time a number of workers found that excess copper was excreted in the urine and that this excretion could be enhanced by the 
administration of BAL (Cumings, 195I ; Porter, 1951). In 1952 Scheinberg and Gitlin demonstrated a defect in cæruloplasmin synthesis in patients with Wilson's disease and at the same time Bearn and Kunkel (1952) showed an associated low level of plasma copper and they, like Cartwright and his associates (1954) in Salt Lake City, believed that the pathogenesis of the disease could be explained by increased copper absorption from the gut, decreased copper incorporation into cæruloplasmin and increased albumin-bound copper permitted an increase in the diffusion of the metal into the tissues where it exerted a toxic action, in the brain leading to basal ganglia degeneration, in the liver to cirrhosis, in the kidneys to renal tubular defects and in the cornea to the characteristic brown pigment deposits, the Kayser Fleischer rings. According to this hypothesis the primary genetic defect was the inability of the liver to synthesize cæruloplasmin. Uzman, Iber, Chalmers and Knowlton (1956) believed the primary defect to be the formation of an abnormal protein by the liver with a specific high affinity for copper and that the copper deposition was merely a secondary phenomenon to which too much attention has been paid.

Studies with radioactive copper have thrown further light on the metabolic abnormality. After oral or intravenous administration of the isotope higher initial blood levels have been found than in normals but there is no rapid fall and secondary rise of plasma activity due to the incorporation of copper into cæruloplasmin which is characteristic of the normal. There is simply a slow disappearance of radiocopper from the plasma so that the ratio of the blood level at 24 hours: 2 hours is greatly reduced; on the other hand more of the isotope is recovered in the urine and less in the stools (Bearn and Kunkel, 1956; Matthews, 1954). To correspond with this slow fall in the concentration of blood copper there is a slow rise in the liver concentration (Bush and others, I955; Osborn and Walshe, 1958, I963; Maytum, Goldstein, McGuckin and Owen, I96I). Indeed the difference in handling of copper by the liver can be demonstrated within a few minutes of the injection by the positioning of scintillation counters over the liver and thigh (Osborn and Walshe, r963); in normals there is an immediate peak of acivity followed by continuous rise in the counting rate over the liver and a low steady or falling counting rate over the thigh, so that the ratio of liver counts to thigh counts increases over the first 15 minutes, whilst in patients with Wilson's disease there is no further rise in liver activity after the initial peak and the liver-thigh ratio remains at unity or falls, an observation which lends no support to Uzman's theory of a high affinity copper-protein in the liver. This reduce uptake of copper by the liver is not related to the blood level of cæruloplasmin or to a previous history of treatment with chelating agents but appears to be an inherent characteristic of the liver of patients with Wilson's disease, suggesting. that the primary metabolic defect may be due to lack of a concentrating enzyme in the liver whick may also have the function of incorporating the metal in the protein moiety of cæruloplasmi (Osborn and others, 1963).

In view of the extreme toxicity of copper when added to purified mitochondrial preparations of sulphydryl enzyme systems it is hard to believe that accumulation of the metal in the brain and liveop which occurs in Wilson's disease is not in some wa related to the cellular lesions. Study of pyruvate. metabolism in patients with Wilson's diseaseg has shown that this is abnormal in a high percene tage of patients (Walshe, I96r) suggesting tha there may be a block to the entry of this ketoacid into the Krebs cycle. This reaction needs for its completion, amongst other factors, glutathion and lipoic acid, both sulphydryl compounds that are vulnerable to copper. In an attempt to thro further light on this problem, Davies, Peters an Walshe (196r) have studied the effect of copper on pyruvate utilisation by the pigeon brain using intact animals, slices and mitochondrial prepara tions. They have demonstrated the extrems toxicity of copper for the intact animal, as little as 20 micograms giving rise to fatal convulsions later they were able to show that only about $20 \%$ of the copper reaches the vulnerable sites in the brai (Peters and Walshe, 1963). They also showe that copper blocked the oxidation of pyruvate b mitochondria but it did not cause a similar metabolic disturbance in brain slices, suggesting that in the intact animal the immediate toxig action of the metal was on the cell surface and not the intracellular enzymes although it is more probable that the latter mechanism is in operatiog in patients with Wilson's disease. The ability of the chelating agents BAL and more particularlo penicillamine to improve the clinical condition of patients with Wilson's disease by the mobilization of body stores of copper also supports the conten tion that copper storage is related to tissue damage in this condition.

As far as the liver is concerned it was not thought until recently to play a large part in the natural history of the disease although it was known that it almost invariably showed cirrhosis and some degree of abnormality of laborator tests. Of recent years however, increasing attent tion has been paid to the hepatic aspect of the disease and characteristic, though not diagnosti histological changes in the liver have beeg 
described by Anderson and Popper (r960) and by Schaffner, Sternlieb, Barker and Popper (1962), and the corresponding clinical reports of Wilson's disease presenting as cirrhosis have also appeared (Chalmers, Iber and Uzman, 1957; Walshe, I962), as have studies of liver function in cases of Wilson's disease with brain involvement (Franklin and Bauman, 1953; Scheinberg and Sternlieb, 1959). As the disease can present in children before the brain is involved one is tempted to ask the relationship of one organ to the other in this condition. The rate of accumulation of copper in the tissues must, to a large extent, be related to the copper content of the diet and the liver, because of its strategic position across the portal blood flow, will necessarily accumulate more of the metal than the brain. This state of affairs may continue either until the liver stores are saturated or until some metabolic change occurs to mobilise these stores and make them available to the brain; such a change will occur at puberty when the increased secretion of œstrogens or androgens can cause a rise in the blood copper concentration, principally the noncæruloplasmin fraction (German and Bearn, 1961; Adelstein and Valee, r 96r). Thus patients with a rapid accumulation of tissue copper will tend to present early as cases of liver damage whilst those with a slower rate of accumulation will present later with brain damage. Patients with early development of liver damage may raise considerable diagnostic problems. The possibility of Wilson's disease should always be considered in children and young adults with obscure liver damage, particularly if other siblings have been similarly affected. If Kayser Fleischer rings are found (which they seldom are before the age of ro years) then the diagnosis is easy but if they are absent then some specific laboratory test must be employed. The finding of a low concentration of copper and cæruloplasmin in the blood is strong supportive evidence for the diagnosis of Wilson's disease for these are normally high in other forms of chronic liver damage (and for that matter in many other acute and chronic infections) but there are other causes of a low blood level of both copper and cæruloplasmin besides Wilson's disease. They may, for instance, be severely depressed in hepatic failure (Walshe and Briggs, 1962), malnutrition, hypoproteinæmia and the nephrotic syndrome but only the first of these conditions is likely to give rise to diagnostic confusion. There is insufficient information about the blood chemistry in 'juvenile cirrhosis' to draw firm conclusions but it is probable that both blood copper and cæruloplasmin are either normal or high in this condition. As rare cases of Wilson's disease have been reported with normal blood levels of copper and cæruloplasmin these estimations alone cannot be used as more than a guide to diagnosis. Urine copper is almost invariably high in Wilson's disease and is probably only elevated in biliary obstruction and biliary cirrhosis amongst other types of liver disease. Excess copper, along with cæruloplasmin and other proteins is also lost in the urine of patients with the nephrotic syndrome. Liver biopsy may also be helpful if the changes described by Anderson and Popper (1960) are carefully sought and a detailed study is made of the intracellular distribution of the metal (Butt and others, 1958). Chemical estimation of the metal in the liver is likely to give rise to confusion between Wilson's disease and 'juvenile cirrhosis' and is probably best not used for this purpose. Studies with radiocopper may be necessary employing all the parameters available, blood levels, the 24 hour to 2 hour ratio, urine excretion and liver uptake. The combination of genetic, clinical, chemical and radiochemical information can usually be relied upon to make the diagnosis clear but occasional cases have been seen in which it is difficult to be certain. If however, there is evidence of disturbed copper metabolism treatment with chelating agents should be started, for heavy copper deposits in the tissues cannot but do harm and their removal may be accompanied with a remarkable clinical improvement.

\section{REFERENCES}

Adelstein, S. J., and Valee, B. L. (1961): Copper Metabolism in Man, New Engl. F. Med., 265, 892 and 941.

Anderson, P. J., and Popper, H. (1960): Changes in Hepatic Structure in Wilson's Disease, Amer. $\mathcal{F}$. Path., 36, 483. BeARN, A. G., and Kunkel, H. G. (1952): Biochemical Abnormalities in Wilson's Disease, $\mathfrak{F}$. clin. Invest., 31, 616.

, (1954): Localisation of $\mathrm{Cu}^{64}$ in Serum Fractions following Oral Administration: An Alteration in Wilson's Disease, Proc. Soc. exp. Biol. (N.Y.), 85, 44.

- - (1955): Metabolic Studies in Wilson's Disease using Cư4, F. Lab. clin. Med., $45,623$.

- (1956): Wilson's Disease, Ergebn. inn. Med. Kinderheilk., 7, 147.

Bickel, H., Neale, F. C., and Hall, G. (1957): A Clinical and Biochemical Study of Hepatolenticular Degeneration (Wilson's Disease), Quart. F. Med., 26, 527.

Bush, J. A., Mahoney, J. P., Markowitz, H., Gubler, C. J., Cartwright, G. E., and Wintrobe, M. M. (i955): Studies on Copper Metabolism. XVI. Radioactive Copper Studies in Normal Subjects and in Patients with Hepatolenticular Degeneration, $\mathcal{F}$. clin. Invest., 34, I 766. 
Butt, E. M., Nusbaum, R. E., Gilmour, T. C., and DiDio, S. L. (1958): Trace Metal Patterns in Disease Statesँ̋ Amer. F. clin. Path., 30, 479.

Cartwright, G. E., Hodges, R. E., Gubler, C. J., Mahoney, J. P., Daum, K., Wintrobe, M. M., and Bean, W. B₹ (1954): Studies on Copper Metabolism. XIII. Hepatolenticular Degeneration, Y. clin. Invest., 33, I487.

Chalmers, T. C., Iber, F. L., and Uzman, L. L. (I957): Hepatolenticular Degeneration (Wilson's Disease) as a Form of Idiopathic Cirrhosis, New Engl. F. Med., 256, 235.

Cumings, J. N. (1948): The Copper and Iron Content of Brain and Liver in the Normal and in Hepatolenticula Degeneration, Brain, 7I, 410.

- (195I): The Effect of BAL in Hepatolenticular Degeneration, Brain, 74, 10.

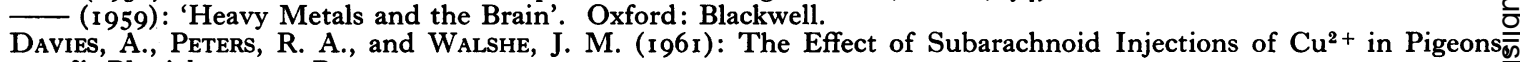
F. Physiol., 159, 32P.

EARL, C. J. (1962): Anatomical Distribution of Copper in Human Brain, in 'Wilson's Disease, Some Current Concepts' Eds. J. M. Walshe and J. N. Cumings. Oxford: Blackwell.

Franklin, E. C., and Bauman, A. (1953): Liver Dysfunction in Hepatolenticular Degeneration, Amer. F. Med., 15, 45o.

German, J. L., and Bearn, A. G. (196I): Effect of CEstrogens on Copper Metabolism in Wilson's Disease, $\mathscr{f}$. clin̄ Invest., 40, 445 .

Gubler, C. J., Brown, H., Markowitz, H., Cartwright, G. E., and Wintrobe, M. M. (i957): Studies on Coppe $\overrightarrow{\vec{E}}$ Metabolism. XXIII. Portal (Laennec's) Cirrhosis of the Liver, F. clin. Invest., 36, I208.

Holmberg, C. G. (1962): Development of Knowledge of Cæruloplasmin, in 'Wilson's Disease, Some Current Concepts'D Eds. J. M. Walshe, and J. N. Cumings. Oxford: Blackwell.

- and Laurell, C. B. (1948): Investigations in Serum Copper. II. Isolation of the Copper-containing Protein and Description of some of its Properties, Acta chem. scand., 2, 550.

Matthews, W. B. (1954): The Absorption and Excretion of Radiocopper in Hepatolenticular Degeneration (Wilson's Disease), $\boldsymbol{F}$. Neurol. Psychiat., 17, 242.

Maytum, W. J., Goldstein, N. P., McGuckin, W. F., and Owen, C. A. (1961): Copper Metabolism in Wilson's Disease, Laennec's Cirrhosis and Hemachromatosis: Studies with Radiocopper $\left(\mathrm{Cu}^{64}\right)$, Proc. Mayo Clin., 36, 641 80

Morell, A. G., Shapiro, J. R., and Scheinberg, I. H. (1962): Copper Binding Protein from Human Liver, in 'Wilson' Disease, Some Current Concepts', Eds. J. M. Walshe and J. N. Cumings. Oxford: Blackwell.

Osborn, S. B., and Walshe, J. M. (1958): Effects of Penicillamine and Dimercaprol on Turnover of Copper in Patients with Wilson's Disease, Lancet, $\mathrm{i}, 70$.

- - (1962): Copper Uptake by the Liver, Study of a Wilson's Disease Family, in 'Wilson's Disease, Some Current Concepts', Eds. J. M. Walshe and J. N. Cumings. Oxford: Blackwell.

- ( 1963$)$ : Unpublished observations.

Roberts, C. N., and Walshe, J. M. (1963): Uptake of Radiocopper by the Liver. A Study of Patients witk Wilson's Disease and Various Control Groups, Clin. Sci., 24, 13.

Peters, R. A., and Walshe, J. M. (1963): Unpublished observations.

Porter, H. (I95I): Copper Excretion in the Urine of Normal Individuals and of Patients with Hepatolentictêtas Degeneration (Wilson's Disease), Arch. Biochem., 31, 262.

- (1962): Copper Protein Combinations in the Brain in Wilson's Disease, in 'Wilson's Disease, Some Current Concepts', Edw. J. M. Walshe and J. N. Cumings. Oxford: Blackwell.

Ravesteyn, A. H. Van (1944): Metabolism of Copper in Man, Acta med. scand., r18, i63.

ReEs, K. R. (1962): Copper as an Enzyme Poison, in 'Wilson's Disease, Some Current Concepts', Eds. J. M. Walshe and J. N. Cumings. Oxford: Blackwell.

Richterich, R. (r962): The Heterogeneity of Caeruloplasmin in the Newborn, in 'Wilson's Disease, Some Current Concepts', Eds. J. M. Walshe and J. N. Cumings. Oxford: Blackwell.

Sass Kortsak, A. (1962): Personal communication.

Schaffner, F., Sternlieb, I., Barker, T., and PopPer, H. (1962): Hepatocellular Changes in Wilson's Disease, Amer্ F. Path., 4I, 3 I 5.

Scheinberg, I. H., and Gitlin, D. (r952): Deficiency of Cæruloplasmin in Patients with Hepatolenticular Degenera tion (Wilson's Disease), Science, I16, 484.

- , and SternlieB, I. (1959): The Liver in Wilson's Disease, Gastroenterology, 37, 550.

- (1960): Copper Metabolism, Pharmacol. Rev., 12, 355.

Uzman, L. L., Iber, F. L., Chalmers, T. C., and Knowlton, M. (1956): The Mechanism of Copper Deposition iæె the Liver in Hepatolenticular Degeneration (Wilson's Disease), Amer. F. med. Sci., 231, 51 I.

Walshe, J. M. (1961): Pyruvate Metabolism in Wilson's Disease, Clin. Sci., 20, r 97.

- (1962): Wilson's Disease: The Presenting Symptoms, Arch. Dis. Childh., 37, 242.

-, and Briggs, J. (1962): Cæruloplasmin in Liver Disease: A Diagnostic Pitfall, Lancet, ii, 263.

Wolff, S. M. (1960): Copper Deposition in the Rat, Arch. Path., 69, 217. 